Int. J. Dev. Biol. 62: 453-464 (2018)

https://doi.org/10.1387/ijdb.180067nn

\title{
The triumvirate of beta-cell regeneration: solutions and bottlenecks to curing diabetes
}

\author{
SUMEET P. SINGH ${ }^{1}$ and NIKOLAY NINOV*,1,2,3 \\ ${ }^{1}$ DFG-Center for Regenerative Therapies Dresden, Cluster of Excellence, Technische Universität Dresden, Dresden, \\ ${ }^{2}$ Paul Langerhans Institute Dresden of the Helmholtz Zentrum München at the University Hospital and \\ Faculty of Medicine Carl Gustav Carus of Technische Universität Dresden, Dresden and \\ ${ }^{3}$ German Center for Diabetes Research (DZD e.V.), Neuherberg, Neuherberg, Germany
}

\begin{abstract}
On 11 January 1922 insulin injection was used for the first time in the treatment of diabetes. Even today, daily insulin injections are the life-saving treatment for patients with Type 1 diabetes and advanced Type 2 diabetes. However, insulin injections often fail to achieve full glucose control, which in the long-term leads to multiple complications and mortality. Beta-cells, the natural producers and secretors of insulin, remain the gold-standard in regulating blood glucose levels. In this review, we focus on three strategies aiming at counteracting beta-cell loss in order to gain insulin independence: replacement, replication and protection. The three approaches, together termed as the triumvirate of beta-cell regeneration, may constitute the basis for a future cure for diabetes.
\end{abstract}

KEY WORDS: reprogramming, regeneration, protection, diabetes

\section{Introduction}

Diabetes mellitus is a metabolic disorder characterized by pathological elevation of blood glucose levels. Sustained hyperglycemia results in tissue damage and secondary complications such as retinopathy, diabetic foot ulcer, neuropathy, cardiovascular diseases and stroke - causing morbidity and mortality. Currently, more than 400 million people worldwide are affected by diabetes. The burden caused by the disease is ever-growing with diabetes incidences increasing by $50 \%$ in the next 25 years, making it an epidemic of the century (Ogurtsova et al., 2017).

The responsibility for maintaining normoglycaemia falls on the beta-cells, located within the islets of Langerhans in the pancreas. Beta-cells sense blood glucose and secrete the hormone insulin in response to elevated glucose levels. Insulin action on target tissues, such as muscle, liver and adipocytes, increases glucose intake and storage (Fig. 1). Lack of sufficient insulin for regulating blood glucose levels underlies development of diabetes (Fig. 1). Type 1 diabetes (T1D), accounting for $10 \%$ of all cases, is characterized by autoimmune attack on the beta-cells resulting in beta-cell loss and insulin deficiency. Type 2 diabetes (T2D), the most prevalent form of diabetes, is characterized by defects in insulin action and insulin secretion (Kahn, 2003). Insulin action is blunted due to peripheral insulin resistance, while insulin secretion can diminish due to beta-cell dysfunction, with advanced T2D cases showing signs of beta-cell loss.

Insulin replacement therapies have been utilized to counteract insufficient insulin in diabetic patients. The first human insulin injection was performed on January 11, 1922 by Banting and Best (Quianzon and Cheikh, 2012). The 14-year old boy receiving insulin injections showed mild reduction in blood glucose levels. Subsequent improvements in insulin purification yielded encouraging results, and won Banting, Best and Macleod the Nobel Prize in 1923. Till date, insulin therapy remains obligatory for T1D and advanced T2D patients.

In-spite of the life-saving impact of insulin therapy, the delivery regimens remain sub-optimal. Bolus insulin injections result in wide fluctuations in glucose levels throughout the day (Bolli et al., 1999), potentially due to the failure to mimic physiological delivery of insulin. Importantly, inaccurate insulin dosing could have deadly consequences of hypoglycemic episodes, a condition of low blood glucose potentially leading to coma and brain death. Thus, it remains critical to find alternative strategies to supply the appropriate amount of insulin to diabetic patients. This review will

\footnotetext{
Abbreviations used in this paper: GSIS, glucose stimulated insulin secretion; hESC, human embryonic stem cell; HTS, high-throughput screen; iPSC: induced pluripotent stem cell: Ngn3, neurogenin 3 (also known as Neurog3); NPM, Ngn3, PDX-1 and MafA factors; PDX-1, pancreas/duodenum homeobox protein 1; STZ, streptozotocine.
} *Address correspondence to: Nikolay Ninov. Center for Regenerative Therapies Dresden (CRTD), Cluster of Excellence atTU Dresden, Fetscherstraße 105
01307 Dresden, Germany. Tel: 0351/458 82314. E-mail: Sumeet_Pal.Singh@tu-dresden.de

Submitted: 20 January, 2018; Accepted: 20 February, 2018.

ISSN: Online 1696-3547, Print 0214-6282 
focus on the beta-cells, the natural providers of insulin. We outline the three most promising cellular strategies aimed at restoring the appropriate mass of functional beta-cells. Replenishment of betacells by the means of replacement, replication and/or protection provide, in principle, the major advantage of achieving autonomous control of blood glucose levels.

\section{The first of the triumvirate: replacement}

In Type 1 diabetes, over $70 \%$ of beta-cell mass is lost (Matveyenko and Butler, 2008), while in Type 2 diabetes, the loss varies between $20-60 \%$ (Cho et al., 2011). The replacement of lost beta-cells via cell replacement therapy has led to multiple cases of diabetes reversal (Ricordi and Strom, 2004; Squifflet et al., 2008). However, the widespread adaptability of cell replacement therapy is hampered by the lack of sufficient transplantation tissue. For example, to achieve insulin independence it is necessary to transplant $\sim 10^{6}$ islets per patient, which requires collection from two to four donor pancreata (Health Quality Ontario, 2015). Donor shortages have restricted cell based therapies to Type 1 diabetic patients that are refractory to all other interventions, also called 'brittle' patients. Therefore, an urgent need exists for developing alternative sources of pancreatic islets. In this section of review, we will focus on two areas that hold the potential to provide an unlimited supply of functional human beta-cells. The two areas include in vitro derivation of beta-cells from pluripotent stem cells or designer beta-cells, and the in vivo reprogramming of somatic cells to beta-cells.

\section{In vitro generation of functional beta-cells from pluripotent stem cells}

Two types of pluripotent stem cells provide the key source for beta-cells: the human embryonic stem cells (hESCs) (Thomson et al., 1998) and induced pluripotent stem cells (iPSCs) (Takahashi et al., 2007). Both pluripotent stem cells provide unlimited proliferative capacity in vitro, enabling access to large quantities of cellular material required for replacement therapies. Differentiation of the pluripotent stem cells towards beta-cells is carried out in a step-wise manner that recapitulates the development of beta-cells in vivo (Pagliuca and Melton, 2013). Cocktails of growth-factors and small molecules are used to coax the pluripotent stem cells through a multi-stage process with clear signposts: definitive endoderm, pancreatic endoderm, endocrine-progenitor and beta-cell. Although the process looks linear and straight-forward, the last step of the differentiation protocol, formation of functional beta-cells, proved to be the most challenging. Initial reports only managed to produce beta-cells with poor glucose-response (D'Amour et al., 2006) or poly-hormonal endocrine cells (Bruin et al., 2014). The poly-hormonal cells produce glucagon and somatostatin along with insulin. However, two promising observations sparked hope that critical factors still need to be discovered in order to achieve formation of functional beta-cells. First, the transplantation of fetal

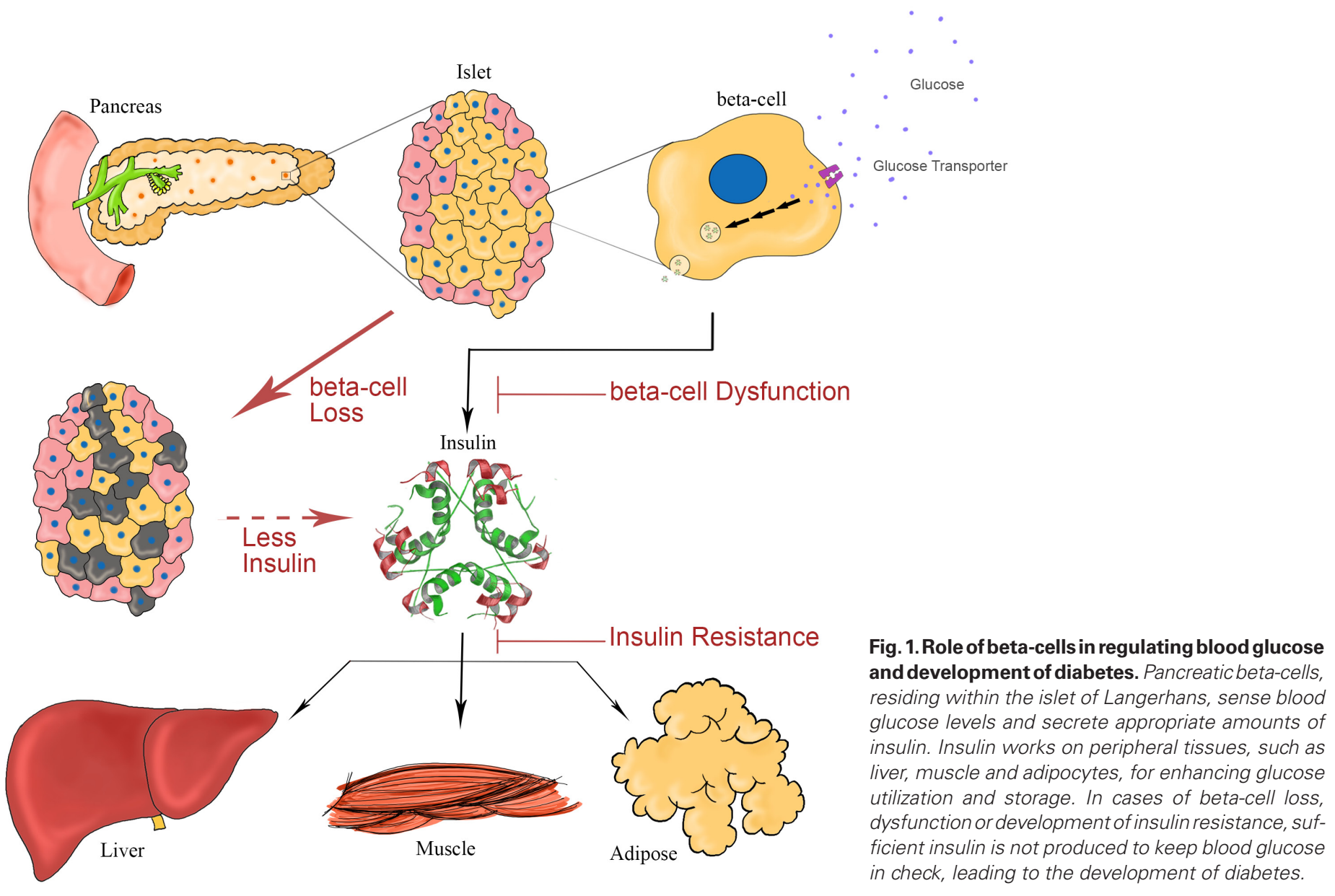




\section{Box 1 - An introduction to beta-cell development}

During mouse development, beta-cells are derived from the distal foregut endoderm in a step-wise manner (Pan and Wright, 2011), which can be visualized by a Waddington landscape (Fig. 2). Regions of the foregut endoderm expressing Pdx1 (pancreatic and duodenal homeobox 1) form two buds of pancreatic endoderm. These buds (a dorsal and a ventral one) fuse and subsequently expand due to the proliferation of the pancreatic progenitors marked by Pdx $1+$ and the basic helix-loop-helix transcription factor Ptf1a (pancreas transcription factor 1a). The pancreatic progenitors subsequently differentiate into committed progenitors for the endocrine and exocrine lineages. The endocrine lineage is pushed along the Waddington landscape by the activation of transcription factors Neurogenin3 (Ngn3), Nkx6.1, and $\mathrm{Nkx2.2.} \mathrm{Terminal} \mathrm{differentiation} \mathrm{of} \mathrm{endocrine} \mathrm{progenitors} \mathrm{into}$ different endocrine cell types involves complex genetic interactions. Specifically, differentiation into alpha-cells involves the expression of the transcription factor Arx and MafB; while the differentiation of beta-cells involves expression of Pax4, which antagonizes Arx function. In addition, suppression of MafB together with the activation of MafA-expression, and the actions of Is|1 and NeuroD1 are all critical for the formation of functional beta-cells. Finally, the exocrine lineage, which give rises to ductal and acinar cells, diverges from the endocrine lineage by active Notch signaling and expression of its downstream target Hes1. Ptf1A continues to be important for acinar differentiation, whereas Sox9 promotes ductal identity.

islet-like clusters into nude mice led to their maturation into glucoseresponsive beta-cell in vivo (Beattie et al., 1997). Furthermore, transplantation of pancreatic endoderm derived from hESCs gave rise to functional beta-cells, which rescued the transplanted mice from STZ-induced hyperglycemia, a model of Type 1 diabetes (Kroon et al., 2008), indicating that the in vivo environment provides critical factors for beta-cell maturation.

The success of differentiating pancreaticendoderm into functional beta-cells in vivostarted a search for the missing factors that could recapitulate the process in vitro. Three simultaneous advances recently showed generation of beta-cells capable of glucose-responsive insulinsecretion (GSIS) in vitro. Rezania et

Fig. 2. Differentiation of pancreatic lineages. The figure represents a Waddington landscape denoting a "mountain" with its various "valleys." The top of the mountain depicts the multipotent gut endoderm, whereas differentiated endocrine and exocrine cells are found at the bottom of the mountain. The cell proceeds from the top of the mountain to the bottom via multiple courses that are defined by activation of specific transcription factors, further outlined in Box 1. al., optimized previous differentiation methods to develop a sevenstage protocol to generate functional beta-cells in vitro (Rezania et al., 2014). The last two stages of the protocol focused on two key transcription factors critical in establishing beta-cell functionality in vivo: NKX6.1 (Taylor et al., 2013) and MafA (Zhang et al., 2005). The authors enhanced expression of NKX6.1 in the stage 6 culture using thyroid hormone (T3), $\gamma$-secretase inhibitor, ALK5 inhibitor, BMP receptor inhibitor and heparin. The ALK5 inhibitor specifically inhibited the sustained expression of NGN3, a transcription factor whose temporally-restricted expression is crucial for formation of diverse endocrine lineages (Johansson et al., 2007). In turn, NGN3 inhibition reduced the formation of polyhormonal cells. The authors subsequently screened for compounds that could induce the expression of MafA, and identified the small molecule (R428), an inhibitor of tyrosine kinase receptor $A X L$, which helped to derive so-called mature stage 7 (S7) beta-cells. The S7 beta-cells showed detectable response to glucose stimulation, as judged by intracellular calcium imaging. However, when compared to human islets, the S7 beta-cells exhibited glucose-induced calcium flux with lower amplitude and a longer time to peak. Even with the dulled characteristics, the S7 beta-cells were capable of reversing hyperglycemia within 40 days in a STZ-induced diabetic mice.

The second report by Pagliuca et al., devised a protocol for generation of beta-cells whose in vivo function appeared to closely resemble that of human beta-cells (Pagliuca et al., 2014). They modified the culture conditions by using a suspension-based 3D culture in contrast to the conventional monolayer culture system, and their new differentiation protocol made several modifications, included the addition of thyroid hormone (T3) and $\gamma$-secretase inhibitor (similar to Rezania et al.) for induction of endocrine fate. The defining feature of the study was the validation of glucose

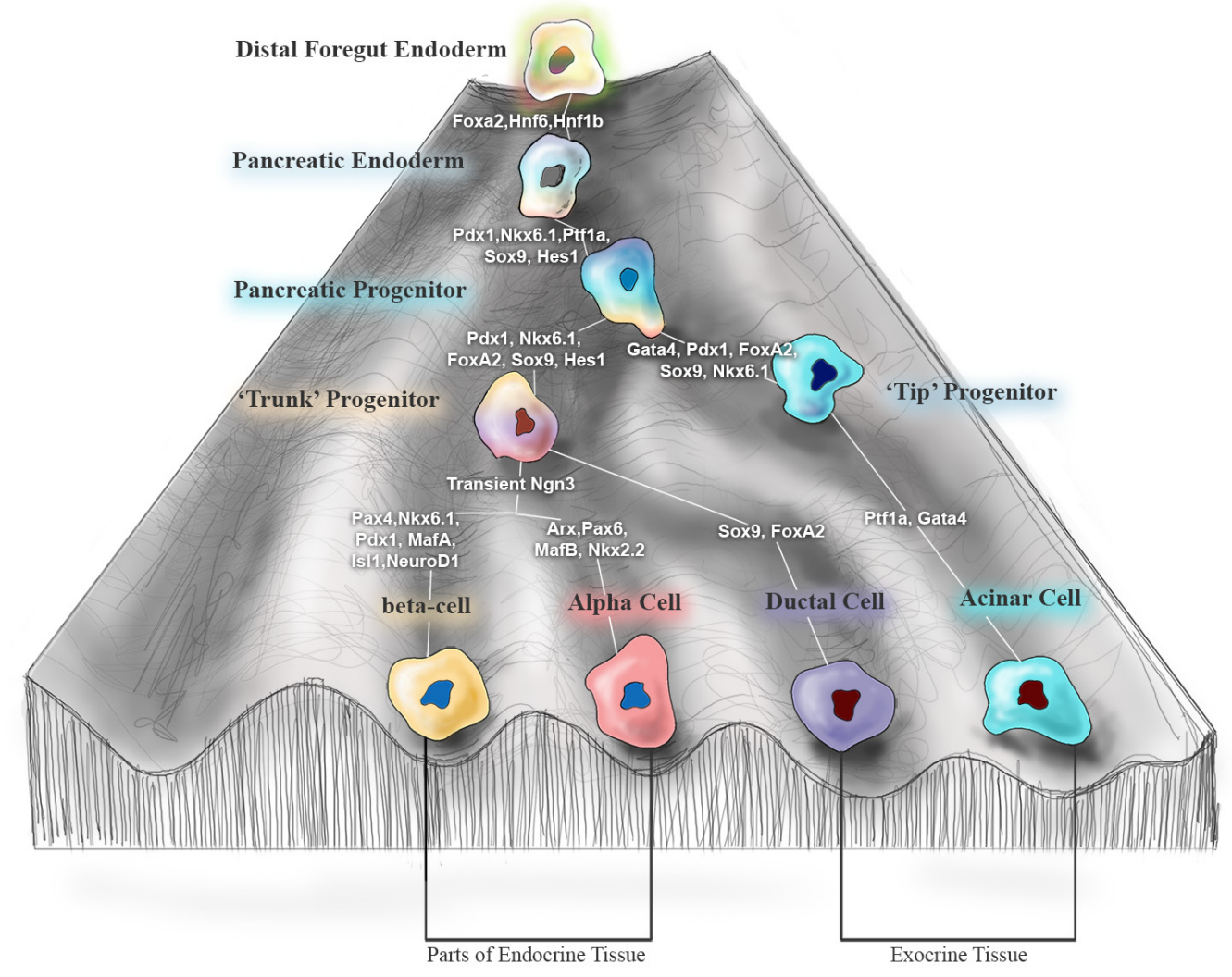


responsiveness for the stem cell-derived beta-cells (SC- $\beta$ cells). SC- $\beta$ cells responded to multiple rounds of glucose challenge, as tested by measuring intracellular calcium flux. Transplantation of SC- $\beta$ cells under the kidney capsule of immunocompromised mice increased human insulin levels following a glucose challenge in $27 / 37(73 \%)$ of animals. Further, SC- $\beta$ cells reduced fasting and post-prandial glucose levels in the Akita mice, a model of diabetes (Yoshioka et al., 1997).

The third report by Russ et al., further refined the protocol for generating functional beta-cells in vitro by recapitulating the sequence of embryonic events required for specification of beta-cell precursors rather than alpha-cell precursors (Russ et al., 2015). They reported that addition of BMP inhibitors in previous procedures led to the formation of polyhormonal cells, and thus avoided their use in their protocol. Additionally, similar to Rezania et al., Russ et al., fine-tuned the culture condition to precisely control the timing of NGN3 expression, enhancing the production of glucose responsive beta-cells. The hESC-derived beta-cells showed glucose responsiveness after transplantation in mice, suggesting their therapeutic potential.

In addition, beta-cells were reported to be generated from fibroblasts without the intermediate pluripotent step (Zhu et al., 2016). Human foreskin fibroblasts were reprogrammed to endodermal progenitor cells by employing non-integrative episomal reprogramming factors (Oct4, Sox2, KIf4 and a short hairpin RNA against p53) in combination with specific growth factors and chemical compounds. The endodermal progenitor cells were differentiated in a step-wise manner towards beta-like cells, though with a fairly conservative (15\%) efficiency. The induced beta-like cells protected mice from STZ-induced diabetes, providing a proof-of-principle of obtaining functional cells directly from fibroblasts. In summary, studies deriving functional beta-cells in vitro represent a significant step towards clinical translation.

\section{Identification of in vivo factors inducing beta-cell maturation}

Differentiation of pluripotent stem cells into mature functional beta-cells in vitro has made tremendous progress, but it still remains inefficient. The differentiation protocols are multiple weeks long, and not all beta-cells generated in vitro respond to glucose. Lessons from developmental biology, which have played a large part in developing existing protocols for in vitro differentiation, could further contribute in improving the robustness of the beta-cell maturation process. In mice and rats, a dramatic process of functional maturation occurs in early postnatal stage, specifically during weaning period when the new born mice switch from mother's milk to solid food (Jacovetti et al., 2015; Stolovich-Rain et al., 2015). Weaning enhances glucose-dependent ATP production in betacells, an intermediate step in GSIS. Transcriptomic comparison of pre-weaned and adult beta-cells revealed upregulation of genes involved in metabolic and mitochondrial activity during maturation (Yoshihara et al., 2016). Specifically, estrogen-related receptor $\gamma$ (ERR $\gamma)$, a key mitochondrial gene regulator, was induced upon beta-cell maturation. Knockout of ERR $\gamma$ reduced GSIS ex-vivo, whereas its over-expression using adenoviruses improved the functionality of beta-cells derived from iPSCs (Yoshihara et al., 2016). Moreover, the ERR $\gamma$ over-expressing beta-cells rescued hyperglycemia in STZ-induced diabetic mouse model. The overexpression of ERR $\gamma$, an orphan receptor, using adenoviruses and the transplantation of 10 million iPSC-derived beta-cells for res- cue experiment might limit the applicability of the system, but the approach offers a promising strategy to discover new factors that mimic the in vivo maturation process during weaning.

In vivo models for visualization and large-scale screening for beta-cell maturation would greatly aid the search for maturity factors. In this case, zebrafish could play a vital role. Work from our group has shown that zebrafish beta-cells become glucose-responsive and express the orthologue of the mammalian maturity marker, urocortin3, within 4 days after birth (Singh et al., 2017). In addition, T3-supplementation enhances zebrafish beta-cell function, in striking agreement with the established differentiation protocols (Matsuda et al., 2017). The short time-window of beta-cell maturation in zebrafish, combined with the optical transparency of zebrafish larvae make it a suitable model for small molecule screens for compounds that enhance or reduce beta-cell maturity. The feasibility and success of such screens remain to be explored.

\section{Designer beta-cells}

In essence, a beta-cell senses glucose and responds by secreting the appropriate amount of insulin. Using synthetic biology, the sensor-responder circuit was artificially engineered in human cells by Fussenegger and colleagues (Xie et al., 2016). The study programmed human embryonic kidney-293 (HEK-293) cells to couple high-levels of extracellular glucose concentration with transcription of insulin and GLP-1 gene. It achieved the coupling by utilizing a genetic cascade of glycolysis-mediated calcium entry to an excitation-transcription system. Quantitative analysis of the glucose-sensing cascade will allow to fine-tune glucose-induced insulin release and functional consistency among the engineered beta-cell mimetics. Microencapsulated designer cells transplanted in a mouse T1D model robustly restored glucose homeostasis for at-least three weeks. The performance of the designer cells was comparable to human islets tested in similar settings. The easy availability of HEK-293 cells, the fine control over the performance parameters and the flexibility to deliver multiple anti-diabetic proteins show that designer beta-cell can become an attractive alternative for beta-cell replacement therapy.

\section{Cell replacement via in vivo reprogramming}

In vivo reprogramming, where the identity of one cell type is switched to another, could provide a promising road towards regenerative therapy. Early example of in vivo reprogramming included transformation of fibroblasts into muscle cells with the use of a single transcription factor, Myod (Davis et al., 1987). It foreshadowed a revolution where cellular identity alterations were pushed to the extreme. Beta-cell regenerative biology is no exception. In this section, we will focus on possible conversions of different somatic cells into beta-like cells in order to augment insulin production in vivo (Fig. 3).

Helpful neighbors: reprogramming pancreatic lineages to beta-cells

The endocrine tissue develops from common progenitors (Fig. 2). The close lineage relationship among endocrine cells raises the possibility that cellular reprogramming could occur with fewer roadblocks. For example, alpha-cells, the cellular neighbors of betacells, were shown to naturally transdifferentiate into beta-cell after near complete beta-cell ablation (Thorel et al., 2010). Moreover, single transcription factor manipulations, such as loss of a Arx or over-expression of PDX-1 or Pax4, were shown to be sufficient 
to promote alpha- to beta-cell conversion in mice (Al-Hasani et al., 2013; Courtney et al., 2013; Yang et al., 2011; Zhang et al., 2016). Importantly, Pax4-mediated alpha- to beta-cell conversion could counter multiple rounds of STZ-treatment mediated diabetes (Zhang et al., 2016). Pharmacologically, $\gamma$-aminobutyric acid (GABA) potentiates this conversion by down-regulating Arx activity (BenOthman et al., 2017). Interestingly, the loss of alpha-cells due to beta-cell conversion was shown to be compensated by de-novo alpha-cells differentiation from progenitors lining the pancreatic ducts (Al-Hasani et al., 2013; Ben-Othman et al., 2017), providing an abundant source for reprogramming. In zebrafish, it was reported that the trans-differentiation event could be enhanced by induction of insulin-like growth factor binding-protein 1 (Igfbp1) (Lu et al., 2016) and requires the action of glucagon gene product (Ye et al., 2015).

Besides the endocrine cells, the exocrine tissue, composed of acinar cells and the branched ductal network, could provide additional cellular sources for reprogramming. Acinar cell fate respecification towards the beta-cell fate was shown to be possible by viral expression of three transcription factors Ngn3, PDX-1 and MafA(NPM factors) (Zhou et al., 2008). Subsequently, improvement in reprogramming efficiency using a single polycistronic construct expressing the NPM factors showed enhanced beta-cell conversion, islet formation and survival for up to 13 months in mice (Li et al., 2014). The induced beta-like cells were reported to acquire GSIS in vivo and reduce hyperglycemia in STZ-treated model of diabetes.

During early development, cells within the vast ductal network of the pancreas naturally generate beta-cells but this progenitor potential declines after birth (Solar et al., 2009). The capacity of adult mammalian ductal cells, or a subset of them, to generate betacells remains controversial (Beer et al., 2016). In contrast, ductal cells in zebrafish retain the ability to generate beta-cells (Delaspre et al., 2015; Ghaye et al., 2015; Ninov et al., 2013). Investigation into the factors that allow adult ductal cells to give rise to beta-cells could open possibilities of reawakening the differentiation capacity of adult human ductal cells. The possibility for such enhancement was demonstrated by over-expression of NPM factors along with Pax6, which transformed ductal cells into beta-cells (Lee et al., 2013). Intriguingly, $2 \%$ of adult human ductal and acinar cells express $\mathrm{Ngn} 3$, and such cells could be differentiated into endocrine cells that resemble beta-cells (Gomez et al., 2015). In addition, NGN3 expression within the ductal cells could be enhanced by the action of cytokines in a STAT3-dependent manner (Valdez et al., 2016). Therefore, manipulating the ductal cells could provide an exciting cellular source of beta-cells.

\section{Diet based enhancement of pancreas plasticity}

Eating a healthy, balanced diet low in carbohydrates is the first advice given to newly diagnosed diabetes patients. Dietary regulation might additionally benefit diabetes therapy by promoting de-novo generation of beta-cells via enhanced cellular plasticity in the pancreas (Cheng et al., 2017). The beneficial role of dietary interventions was recently revealed by placing STZ-treated mice on weekly cycles of 4-day fasting-mimicking diet (FMD) followed by 3 days of regular diet. Notably, this study reported that STZ-induced hyperglycemia was corrected within 60 days in mice on FMD, but not in ad libitum fed animals. Detailed molecular and histological analysis revealed an upregulation of developmental genes including Sox17 and NGN3 in pancreatic islets of FMD fed animals and a role for the $\mathrm{Ngn} 3+$ cells in the generation of de-novo beta-cells. The potential benefit of FMD on enhancement of beta-cell mass, in addition to its improvement of insulin sensitivity, suggest that pancreatic plasticity can be induced even without the over-expression of transcription factors. Further studies will be necessary to determine the feasibility of this approach for clinical applications in beta-cell regeneration.

\section{De(Liver)ing beta-cells}

Harnessing the liver as a cellular source for beta-cells presents an encouraging opportunity because of its close developmental origin with the pancreas, as well as its high regenerative capacity. Liver cells can be reprogrammed to beta-cells by expression of a

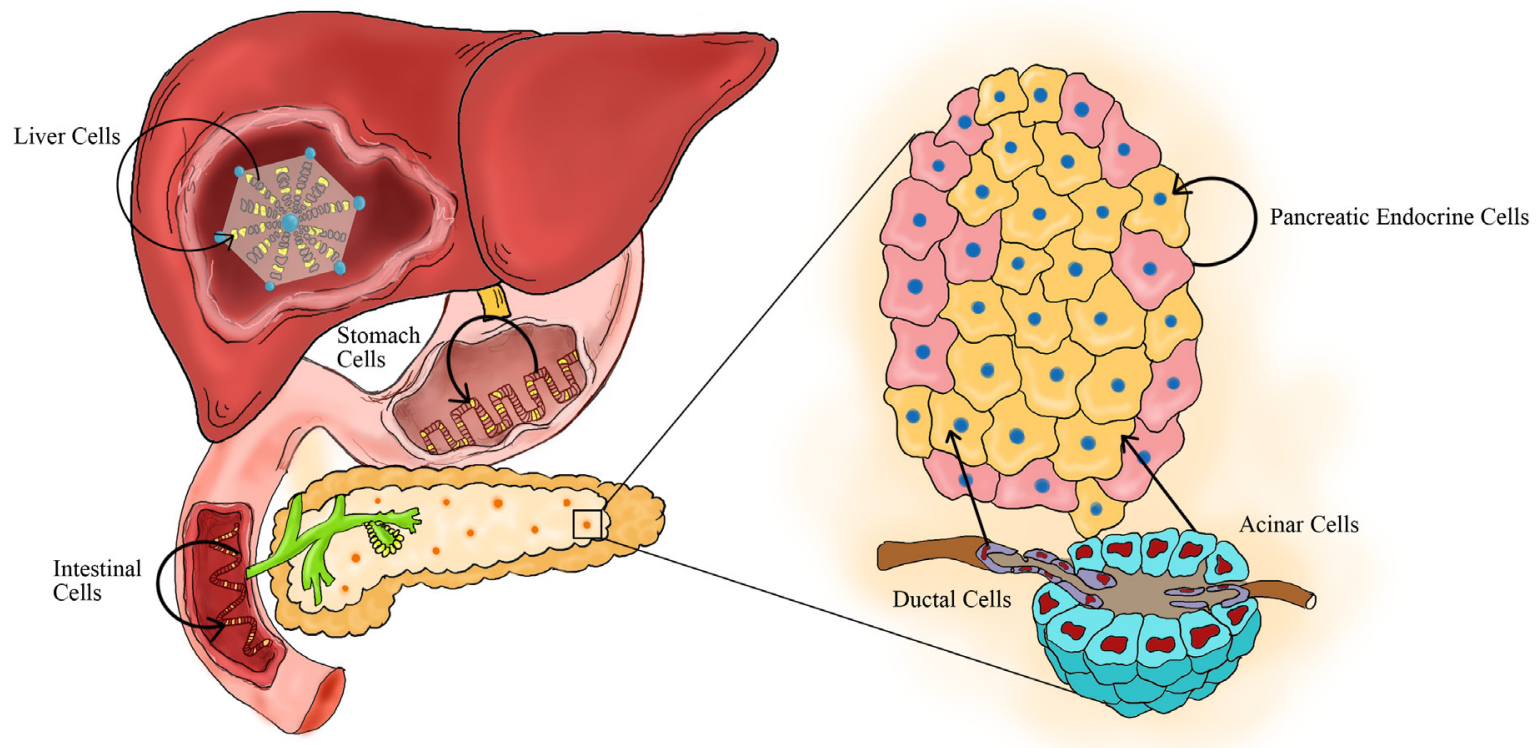

Fig. 3. Cellular sources for in vivo reprogramming into beta-cells. Terminally differentiated somatic cells can be used to generate beta-cells in vivo by changing their cellular identity. Pancreatic endocrine and exocrine cells, liver, stomach and intestinal cells provide a viable source for cellular reprogramming. 
single transcription factor, PDX-1 (Ferber et al., 2000). However, PDX-1 alone could transform less than $1 \%$ of hepatocytes. Improvement in efficiency of transformations were made possible by co-expression of additional endocrine transcription factors, Ngn3, MafA, Pax4 or NeuroD along with PDX-1 (Berneman-Zeitouni et al., 2014; Ham et al., 2013). In addition to hepatocytes, Sox9+ bile duct cells of the liver can also be reprogrammed by a polycistronic vector containing Ngn3, PDX-1 and MafA (NPM factors) (Banga et al., 2012).

In an alternative strategy, hepatocytes were reprogrammed to pancreatic progenitor-like state by expression of a TALE homeoprotein, TGIF2 (Cerdá-Esteban et al., 2017). TGIF2 is developmentally expressed and controls the pancreas versus liver decision in the endoderm. Notably, tgif2 misexpressing hepatocytes underwent transcriptional remodeling and were specified towards the pancreatic lineage. The pancreatic progenitor-like cells generated in vitro were transplanted into the Akita mouse model of diabetes, wherein they differentiated to produce urocortin3+ and insulin+ cells and reduced blood glucose levels, suggesting their therapeutic potential.

Reprogramming of liver cells to beta-cells could have potential clinical impact since liver offers a permissive location for long-term survival and functionality of beta-cells, as suggested by the delivery of islets into the liver via the portal vein during human islet transplantation. However, care needs to be taken to generate properly differentiated structures, as constitutive expression of PDX-1 in liver has been shown to cause abnormalities in lobe structures and multiple cystic lesions (Miyatsuka et al., 2003).

Harnessing the regenerative potential of gut to rejuvenate betacell mass

Human gut epithelium has an estimated turnover of 100 billion cells per day (Barker, 2013). Reprogramming the gut to insulin producing cells would benefit from the highly proliferative cellular source. In vivo reprogramming of gut cells was first shown with the ablation of FOXO1 transcription factor in Ngn3 expressing cells (Talchai, Xuan, Kitamura, et al., 2012). Ngn3 expression marks progenitor cells for pancreatic endocrine and the gut enteroendocrine lineage (Schonhoff et al., 2004). Knockout of FOXO1 increased the expression of beta-cell transcription factors PDX-1, MafA and Nkx6.1, and induced expression of insulin likely via the miss-differentiation of the gut enteroendocrine cells into insulin-producing cells. The therapeutic potential of beta-like cells resulting from FOXO1 inhibition might be restricted due to the important role of FOXO1 in beta-cell functional (Kobayashi et al., 2012). Thus, it will be important to develop means to induce reprogramming without interfering with FOXO1 function. For instance, recently, cells in the intestine and the stomach could also be reprogrammed to beta-like cells using the expression of NPM factors (Ngn3, PDX-1 and MafA) (Ariyachet et al., 2016; Chen et al., 2014). NPM expression in the intestine generated transient islet-like structures containing both insulin and glucagon-expressing cells. It will be important to develop pharmacological cocktails that can induce this reprogramming in order to explore the feasibility of this approach for clinical translation.

Apart from genetic manipulations, conversion of intestinal epithelial tissue was shown by stimulation with the inactive full-length form of glucagon-like peptide -1 (GLP-1 ${ }_{(1-37)}$ ) (Duan et al., 2015). GLP-1 ${ }_{(1-37)}$ was delivered via expression in human lactobacilli that was administered orally in rats or in vitro to human epithelial tis- sue. In both instances, transformation of gut cells to beta-cells was observed along with expression of MafA and PDX-1. Rats treated with GLP-1 ${ }_{(1-37)}$ displayed reduced hyperglycemia in STZ-induced model of diabetes. The efficacy of the approach in humans remains to be determined, but would be interesting to couple this approach with the probiotics revolution in managing disease.

\section{The second of the triumvirate: replication}

Within 5 years of birth, we have established most of the beta-cell population that will serve us throughout life (Gregg et al., 2012). The establishment of beta-cell mass includes a short burst of beta-cell proliferation during infancy, with the rate of replication decreasing as one gets older (Meier et al., 2008). In adulthood, periods of accelerated increase in beta-cell mass are restricted to times of intense metabolic demand, such as obesity or insulin resistance (Klöppel et al., 1985; Saisho et al., 2013). For instance, induction of insulin resistance in mouse hepatocytes triggers the expression of the secreted protein, SerpinB1, which can stimulate beta-cell replication in mouse and human islets (El Ouaamari et al., 2016).

The possibility to treat diabetes by beta-cell replication has been validated in mice, where specific and conditional genetic ablation of a subset of beta-cells induced regeneration via proliferation of the spared beta-cells (Nir et al., 2007; Shamsi et al., 2014). Similar to humans, the adult beta-cell population in mice is established during postnatal stage in large part by replication of differentiated beta-cells (Dor et al., 2004). However, the rate of adult human beta-cell proliferation, unlike in mice, is much lower, which can be attributed to specie-specific differences in beta-cell proliferative capacity (Kulkarni et al., 2012; PWang, Fiaschi-Taesch, et al., 2015). Factors that enhance human beta-cell proliferation might aid in recapitulating the success of beta-cell regeneration as observed in the mouse models. A clear overview of molecular mechanisms underlying beta-cell proliferation, mostly emerging with the help of numerous mouse models, have been reviewed extensively (Bernal-Mizrachi et al., 2014; Kulkarni et al., 2012; P Wang, Fiaschi-Taesch, et al., 2015); so we will summarize recent advances in identifying promising pharmacological, molecular and cellular candidates.

\section{High-throughput screens (HTS) to identify inducers of mammalian beta-cell proliferation}

Our knowledge of the molecular players involved in beta-cell proliferation can be expanded by performing large-scale unbiased screens to identify small molecules that promote proliferation. Wang et al., employed this approach to device a high-throughput screen (HTS) targeting the induction of cMYC (P Wang, Alvarez-Perez, et al., 2015), a potent driver of human beta-cell proliferation (Karslioglu et al., 2011). Human hepatocyte cell line (HepG2) transformed with a MYC responsive element driving luciferase was used to screen 102,300 compounds for their impact on luciferase levels as a proxy for MYC expression. Of the 86 top-hits, one compound, Harmine, induced robust BrdU incorporation, a read-out of DNA synthesis during S-phase of cell cycle, in rodent and human beta-cells. The ability of harmine to stimulate human beta-cell proliferation was tested in STZ-induced diabetic mouse following transplantation of human islets. Transplantation of a limited amount of human islets in this diabetic mouse could not normalize blood glucose levels. However, harmine treatment of the islet-recipients rescued 
hyperglycemia, potentially by enhancement of beta-cell mass via harmine-induced beta-cell proliferation. Harmine likely induces proliferation by inhibiting dual-specificity tyrosine-regulated kinase1a (DYRK1A), which in turn activates calcineurin-NFAT (nuclear factors of activated $T$ cells) signaling. The screen was based on a hepatocyte cell line, and thus might miss beta-cell specific mitogenic factors. To circumvent the issue, Walpita et al., developed a protocol for direct screening of proliferation in human islets (Walpita et al., 2012). Human islets were seeded onto custom processed culture plates to screen 1280 compounds for their potential to induce beta-cell proliferation, assayed by Ki67 and C-peptide costaining. The authors tested GSIS of the cultured islets to ensure the health and functionality of beta-cells. Although the results of the screen remain un-published, the culture system was used to validate harmine as a potent stimulation of human beta-cell replication (Dirice et al., 2016). The two studies illuminate the capacity to identify new mitogenic compounds, but translation in vivo would require testing beta-cell specificity and safety.

\section{Fishing for compounds that increase beta-cell proliferation in vivo}

Interventions capable of inducing human beta-cell replication in vivo remain limited, potentially due to the lack of tools to screen for compounds that induce the endogenous proliferative capacity of beta-cells. Zebrafish, with its small size, rapid development, and transparency, offers an opportunity for pharmacological screens for beta-cell proliferation in a living animal, as demonstrated by three studies. Using a system for conditional beta-cell ablation, Andersson et al., 2012 screened for compounds that stimulate beta-cell regeneration. Notably, the most potent hit NECA, stimulated beta-cell proliferation in zebrafish and mouse islets via the adenosine receptor-activation (Andersson et al., 2012). In the second report, Tsuji et al., developed an in vivo imaging approach that specifically labelled proliferative beta-cells using a fluorescent ubiquitylation-based cell cycle indicator (FUCCI) (Tsuji et al., 2014). The FUCCI genetically marks cells in S/G2/M phase with green fluorescent protein, and the label was restricted to beta-cells via transgenic expression from the insulin promoter. In a screen of 883 small molecules, 20 potential stimulators were identified, among which several compounds enhanced serotonin signaling, which is known to induce mouse beta-cell replication (Kim et al., 2010). The screen was, however, based on high-content image analysis, which prevented high through-put screening. To improve through-put, Wang et al., developed an automated platform for measuring drug and embryo dispersion along with software-assisted quantification of beta-cell number (G Wang et al., 2015). Importantly, automatization of the screen allowed the authors to screen over 500,000 zebrafish larvae at multiple concentrations of each compound. The study reported 15 drugs that stimulated beta-cell proliferation, along with 9 additional compounds that increases beta-cell mass via progenitor differentiation. Interestingly, as the FUCCl-based screen, the automated screen also identified drugs involved in modulating the activity of the serotonin pathway. Altogether, these three studies showed the important role for zebrafish in identifying compounds that can stimulate beta-cell proliferation in vivo, however, successful examples translating the findings from zebrafish to human beta-cells are yet to be shown.

\section{Is there a dedicated population of proliferative and functional beta-cells?}

The dual task of cell division and insulin release, two energetically demanding processes, place a heavy workload on beta-cells. It is hypothesized that not all beta-cells take equal part in the proliferative and functional tasks (Bader et al., 2016; Singh et al., 2017). For example, in mouse, the flattop (Fltp, also called Cfap126) gene distinguishes the proliferative population from the functional one (Bader et al., 2016). In islets of postnatal mice with a knock-in of histone 2B-Venus cassette in the Fltp locus, beta-cells display heterogeneous Fltp-expression. Specifically, the Fltp+ beta-cells show lower replication rate during postnatal expansion phase as compared to the Fltp- beta-cells. Additionally, the Fltp-population preferentially expands during pregnancy, suggesting that the Fltp-cells form a sub-population dedicated preferentially towards increasing the beta-cell mass rather than increasing the function. Interestingly, the two populations might not be stable as lineage tracing of Fltp- population showed transformation of certain Fltpbeta-cells into Fltp+ beta-cells.

Along with the heterogeneity in the proliferative capacity among beta-cells, the functional capacity has also been shown to vary. Mouse beta-cells display synchronized, rhythmic activity upon glucose stimulation, which was shown to be attributed to a small subset of beta-cells within the islet (Johnston et al., 2016). These highly sensitive beta-cells, termed hub cells, were demonstrated to stimulate coordinated activity within the islet beta-cells. Additionally, silencing of hub cells specifically disturbed the coordinated islet response, suggesting a bona-fide role of these cells in generating beta-cell rhythm, similar to the pacemaker cells of the heart.

In contrast to the functionally important hub-cells, a population of immature and less functional beta-cells was identified at the periphery of the mammalian islet (van der Meulen et al., 2017). The immature beta-cells expressed insulin, but lacked makers of beta-cell maturity, including urocortin3, and could not respond to glucose stimulation. The immaturity of the beta-cells at the

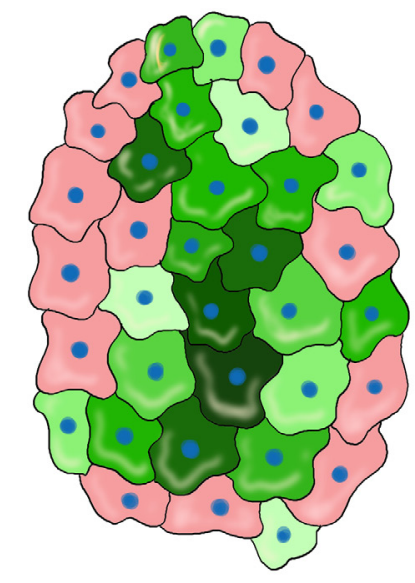

Fig. 4. Example of beta-cell heterogeneity. A cartoon depicting functional heterogeneity among beta-cells. Beta-cells with diverse functional capacity, colored with different shades of green, are present within the same islet. This functional heterogeneity might reflect differences in differentiation age or replicative potential. 
periphery was attributed to the cells being in an intermediate differentiation state, wherein with time these young beta-cells would acquire functionality. Such time-dependent maturity of differentiating beta-cells has also been suggested by our own work on zebrafish beta-cells. Using lineage tracing and calcium imaging, we showed that beta-cell neogenesis during the post-embryonic stages of zebrafish development generates proliferative but less functional beta-cells. These newborn cells transition to a more functional state with increasing time since cell birth (Singh et al., 2017). Thus, the functional heterogeneity within beta-cells could be attributed, in part, to subpopulations of beta-cells being present in different stages of their life cycle. In this regard, a recent study identified novel molecular markers of beta-cell aging (Aguayo-Mazzucato et al., 2017). As expected, the proportion of aged beta-cells in islets increased with time, but interestingly, the ratio of aged to young beta-cells differed within the multiple islets of the same pancreas. Inter-islet (between beta-cells), as well as intra-islet heterogeneity was observed, suggesting that each islet could exist as a miniorgan with its own history and functional properties.

In summary, the beta-cell population might dynamically segregate functional and proliferative responsibilities to sub-populations (Fig. 4). It would be of interest to find receptors and genetic networks specific to each sub-populations. The differentially expressed genes could become important targets for regulating the proliferative or functional pool of cells.

\section{Exploiting heterogeneity to identify molecular regulators of beta-cell proliferation}

The diversity between beta-cells suggests that the beta-cell population is composed of proliferative, quiescent, functionally mature, and immature cells (Bader et al., 2016; Dorrell et al., 2016; Qiu et al., 2017; Singh et al., 2017). The beta-cell states could be dynamic, and shift between proliferation and function. Resolving transitions between developmental states is made possible by 'pseudotemporal' analysis (Trapnell et al., 2014). Pseudotemporal analysis involves ordering of single cells along a line connecting an initial state to final state. Genetic changes that correlate with the ordering of cells might regulate the transition. Zeng et al., exploited the pseudotemporal ordering of single beta-cells collected from mice during the first month of post-natal life to develop a transition from proliferative to mature state (Zeng et al., 2017). The analysis revealed signature of the proliferative beta-cell state, which included high expression of Activator protein 1 (AP-1) transcription factors and genes involved in mitochondrial respiration. Enhanced mitochondrial respiration leads to reactive oxygen species (ROS) production, a potential inducer of cell proliferation (Boonstra and Post, 2004). The role of ROS in beta-cell proliferation was validated by over-expression of catalase, a ROS scavenger. Beta-cell specific over-expression of catalase drastically reduced the proliferation, without affecting its apoptosis or the capacity to secrete insulin upon glucose challenge. The study elegantly exploits the heterogeneity in beta-cell population to reveal the requirement of ROS production for beta-cell proliferation. However, ROS is a double-edged sword, with high levels causing G2/M cell cycle arrest (Boonstra and Post, 2004). The inhibitory effect of high-levels of ROS on beta-cell proliferation was shown in zebrafish beta-cells (Ahmed Alfar et al., 2017). Zebrafish beta-cells, similar to mouse counterparts, show reduced proliferation upon cell specific expression of catalase; implicating a conserved role for ROS in beta-cell replication. However, high levels of ROS, induced by treatments with hydrogen peroxide $\left(\mathrm{H}_{2} \mathrm{O}_{2}\right)$, also inhibited proliferation. In contrast, moderate increase in ROS, with treatment with lower concentrations $\mathrm{H}_{2} \mathrm{O}_{2}$ stimulated beta-cell proliferation. Altogether, the mouse and zebrafish studies challenge the beneficial role of antioxidants in diabetes therapy, as they clearly show the positive role of moderate levels of ROS in stimulating beta-cell proliferation.

\section{Can gut microbiota regulate beta-cell proliferation?}

The human gut microbiota harbors more than 1000 bacterial species with almost 150-fold more genes than found in human genome (Qin et al., 2010). The microbiota could be referred to as a hidden metabolic 'organ' due to its immense impact on nutrition, energy consumption and immunity, which could ultimately influence susceptibility to obesity and diabetes (Musso et al., 2011). In a study by Guillemin and colleagues using zebrafish born and raised in germ-free conditions, the authors found decreased betacell mass in animals devoid of microbes, suggesting a link between microbiota and beta-cell proliferation (Hill et al., 2016). The authors identified a novel bacterial protein, BefA ( $\beta$ Cell Expansion Factor $A)$, as a possible candidate gene influencing beta-cell proliferation in early stages of life. BefA over-expression was able to rescue the reduction in beta-cell mass of animals raised in germ-free conditions. The receptor for BefA remains unknown, and thus the cellular specificity and a direct link between beta-cells and gut-microbiota is still missing. Nevertheless, the study adds an exciting player in beta-cell biology: our body's microbial guests.

\section{The third of the triumvirate: protection}

Beta-cell mass is significantly reduced in patients of Type 1 and Type 2 diabetes (Matveyenko and Butler, 2008). In both forms of diabetes, a window exists for potentially saving the beta-cells. In Type 1 diabetes, following the initiation of insulin treatment, a partial remission of almost a month occurs during which good glycemic control is maintained with low insulin requirement, which is also referred to as 'the honeymoon period'. For Type 2 diabetes, the prediabetic stage could last for a few years. During these timeperiods, preventing the loss of beta-cells provides a preemptive strategy against reduction of beta-cell mass. In this section, we focus on recent advancements in protecting the beta-cell mass and delineating the cellular mechanisms underlying beta-cell loss.

\section{Protection of beta-cells from cytokine mediated apoptosis by epigenetic modifications}

Beta-cell loss via apoptosis in both Type 1 and Type 2 diabetes share certain inflammation-mediated signal transduction pathways (Donath and Halban, 2004). Specifically, a pathway involving nuclear factor (NF)-kappaB, cytokines and the Fas ligand is suggested to be central to inflammation-mediated beta-cell death. Efforts at utilizing broad spectrum epigenetic modifiers in inhibiting pro-inflammatory pathways in multiple cell types has shown promising results (Patel et al., 2011). Specifically, histone deacetylases (HDACs) inhibitors were shown to block cytokine-induced beta-cell apoptosis in vitro and in the NOD mouse model of Type 1 diabetes (Lewis et al., 2011). Recently, another family of epigenetic modifiers, the Bromodomain and Extra-Terminal Domain (BET), was implicated in loss of betacells in Type 1 diabetes. The inhibition of BET proteins by small 
molecule I-BET151 suppressed development of diabetes in the non-obese diabetic (NOD) model (Fu et al., 2014). I-BET151 inhibited NF-kappaB pathway in pancreatic macrophages, and reduced inflammatory phenotype among them, as judged by transcriptional profiling. Additionally, the drug induced beta-cell regeneration in the anti-inflammatory environment. Immune responses involve wide ranging transcriptional and epigenetic alterations. Epigenetic modifications may play a larger role than currently appreciated, as evidenced by the fact that the majority of the single nucleotide polymorphisms (SNPs) associated with diabetes were found to be present in non-coding regions of the human genome (Pasquali et al., 2014). Inhibiting epigenetic modifications with small-molecule inhibitors provide a promising but evolving strategy.

\section{Protection of beta-cells from glucolipotoxicity}

Glucolipotoxicity, defined by elevated levels of glucose and lipids, underlies the multi-organ failure characterizing the later stages of diabetes. Glucolipotoxicity also negatively affects beta-cells by increasing ER stress and oxidative damage (Poitout and Robertson, 2008). This impairs proper protein folding, leading to elevation of the unfolded protein response that reduces glucose-stimulated insulin secretion, further exacerbating unregulated blood glucose levels (Back and Kaufman, 2012). Pharmacological agents known to reduce functional stress in beta-cells, including anti-diabetic drugs such as incretin-mimetic agents and PPAR-gamma agonists or GSK3 $\beta$ inhibitors, have also been shown to provide a protective effect on human beta-cells (Dalle et al., 2013; Gupta et al., 2010; Mussmann et al., 2007; Shimoda et al., 2011). Their protective role makes them suitable for treatment during pre-diabetic and early stages of Type 2 diabetes.

Beta-cell loss via apoptosis is not the only path towards beta-cell loss. Reduction in beta-cell mass has also been shown to occur by loss of beta-cell identity, which involves inactivation of genes involved in beta-cell maturity and function. In a mouse model of insulin-resistance, adult beta-cells were shown to revert to a progenitor-like state marked by reduction in key functional genes, including insulin, Pdx1 and MafA, while activating Ngn3, Oct4 and c-Myc (Talchai, Xuan, Lin, et al., 2012). Furthermore, a mouse model of hyperglycemia, the $d b / d b$ mice, showed inactivation of beta-cell specific transcription factors, including MafA, Nkx6.1 and Pdx1 (Guo et al., 2013). Reversion of mature beta-cell state to fetal-like state is also suggested by ectopic expression of gastrin in beta-cells from diabetic rodents and humans (Dahan et al., 2017). Gastrin is a stomach hormone expressed in pancreas only during embryogenesis. The promising side of dedifferentiation, as opposed to apoptosis, is that the loss could potentially be reversible as dedifferentiated beta-cells possess the capacity to differentiate again to contribute to the beta-cell mass (Wang et al., 2014). A screen for drugs that inhibit beta-cell dedifferentiation identified Alk5 inhibitor as a potent small molecule capable of blocking reversion of beta-cell identity (Blum et al., 2014). Understanding the dedifferentiation process and targeting the population of immature beta-cells by small molecules offer a potential therapy for restoring the lost beta-cells.

\section{A world without diabetes}

Efforts towards establishing normal blood glucose levels in diabetic patients worldwide has substantially improved with the progress in recombinant insulin and insulin delivery methods. Yet, secondary complications arising due to diabetes claim more than 5 million lives yearly (Ogurtsova et al., 2017). We have outlined the three major beta-cell specific interventions that might accomplish the goal of euglycemia maintenance without exogenous insulin delivery. The interventions are aimed at re-establishing appropriate beta-cell mass, the gold standard in maintaining blood glucose levels. One of interventions, replacement, is currently ongoing clinical trials initiated by Viacyte. The phase I to II investigation with Food and Drug Administration involves use of trademarked VC-01 combination product of PEC-01 (pancreatic progenitor cells) in a durable macroencapsulation device (ClinicalTrials.gov identifier NCT02239354). As we optimistically await the results of the clinical trial, it is worth mentioning that it will be important to establish whether cells within a macroencapsulation device effectively sense glucose and release insulin in the absence of a direct contact with endothelial cells, which is a characteristic feature of the native environment of beta-cells. In addition, while a capsule confines the cells, it will not prevent the release of unwanted growth factors and even the exchange of genetic material via release of exosomes, posing safety concerns. Finally, protecting the transplanted cells from the stress associated with nutrient-deprivation, hypoxia and the presence of soluble cytokines might become critical for the success of this approach. Therefore, a multi-disciplinary approach combining the expertise from multiple fields: developmental biology, clinical practice, material science and many more, provides the best chance at subjugating diabetes. In addition, enhancing the beta-cell mass in vivo via reprogramming, replication or protection will remain topics of intense investigation due to their high promise for curing diabetes.

\section{Acknowledgements}

We thank Priyanka Oberoi for figures; Sharan Kaur Janjuha for comments on the manuscript. We apologize to our colleagues in the field for omitted citations due to restrictions on space and number of references. N.N. is supported by funding from the DFG-Center for Regenerative Therapies Dresden, Cluster of Excellence at TU-Dresden and the German Center for Diabetes Research (DZD), as well as research grants from the German Research Foundation (DFG), the European Foundation for the Study of Diabetes (EFSD) and the DZD.

\section{References}

AGUAYO-MAZZUCATO C, VAN HAAREN M, MRUK M, LEE TB, CRAWFORD C HOLLISTER-LOCK J, SULLIVAN BA, JOHNSON JW, EBRAHIMI A, DREYFUSS JM, VAN DEURSEN J, WEIR GC, BONNER-WEIR S (2017). $\beta$ Cell Aging Markers Have Heterogeneous Distribution and Are Induced by Insulin Resistance. Cell Metab 25: 898-910.e5.

AHMED ALFAR E, KIROVA D, KONANTZ J, BIRKE S, MANSFELD J, NINOV N (2017). Distinct Levels of Reactive Oxygen Species Coordinate Metabolic Activity with Beta-cell Mass Plasticity. Sci Rep 7: 3994.

AL-HASANI K, PFEIFER A, COURTNEY M, BEN-OTHMAN N, GJERNES E, VIEIRA A, DRUELLE N, AVOLIO F, RAVASSARD P, LEUCKX G, et al., (2013). Adult Duct-Lining Cells Can Reprogram into $\beta$-like Cells Able to Counter Repeated Cycles of Toxin-Induced Diabetes. Dev Cell 26: 86-100.

ANDERSSON O, ADAMS BA, YOO D, ELLIS GC, GUT P, ANDERSON RM, GERMAN MS, STAINIER DYR (2012). Adenosine signaling promotes regeneration of pancreatic $\beta$ cells in vivo. Cell Metab 15: 885-894.

ARIYACHET C, TOVAGLIERI A, XIANG G, LU J, SHAH MS, RICHMOND CA, VERBEKE C, MELTON DA, STANGER BZ, MOONEY D, SHIVDASANI RA, MAHONY S, XIA Q, BREAULT DT, ZHOU Q (2016). Reprogrammed Stomach Tissue as a Renewable Source of Functional $\beta$ Cells for Blood Glucose Regulation. Cell 
Stem Cell 18: 410-421.

BACK SH, KAUFMAN RJ (2012). Endoplasmic Reticulum Stress and Type 2 Diabetes. Annu Rev Biochem 81: 767-793.

BADER E, MIGLIORINI A, GEGG M, MORUZZI N, GERDES J, ROSCIONI SS, BAKHTI M, BRANDL E, IRMLER M, BECKERS J, et al., (2016). Identification of proliferative and mature $\beta$-cells in the islets of Langerhans. Nature 535: 430-434.

BANGA A, AKINCI E, GREDER L V., DUTTON JR, SLACK JMW (2012). In vivo reprogramming of Sox9+ cells in the liver to insulin-secreting ducts. Proc Natl Acad Sci 109: 15336-15341.

BARKER N (2013). Adult intestinal stem cells: critical drivers of epithelial homeostasis and regeneration. Nat Rev Mol Cell Biol 15: 19-33.

BEATTIE GM, OTONKOSKI T, LOPEZ AD, HAYEK A (1997). Functional beta-cell mass after transplantation of human fetal pancreatic cells: differentiation or proliferation? Diabetes 46: 244-248.

BEER RL, PARSONS MJ, ROVIRA M (2016). Centroacinar cells: At the center of pancreas regeneration. Dev Biol 413: 8-15.

BEN-OTHMAN N, VIEIRA A, COURTNEY M, RECORD F, GJERNES E, AVOLIO F, HADZIC B, DRUELLE N, NAPOLITANO T, NAVARRO-SANZ S, et al., (2017). Long-Term GABA Administration Induces Alpha Cell-Mediated Beta-like Cell Neogenesis. Cell 168: 73-85.e11.

BERNAL-MIZRACHI E, KULKARNI RN, SCOTT DK, MAUVAIS-JARVIS F, STEWART AF, GARCIA-OCAÑA A (2014). Human $\beta$-cell proliferation and intracellular signaling part 2: still driving in the dark without a road map. Diabetes 63: 819-831.

BERNEMAN-ZEITOUNI D, MOLAKANDOV K, ELGART M, MOR E, FORNONI A, DOMÍNGUEZ MR, KERR-CONTE J, OTTM, MEIVAR-LEVYI, FERBERS (2014). The temporal and hierarchical control of transcription factors-induced liver to pancreas transdifferentiation. PLoS One 9: e87812.

BLUM B, ROOSE AN, BARRANDON O, MAEHR R, ARVANITES AC, DAVIDOW LS, DAVIS JC, PETERSON QP, RUBIN LL, MELTON DA (2014). Reversal of $\beta$ cell de-differentiation by a small molecule inhibitor of the TGF $\beta$ pathway. Elife 3 .

BOLLI GB, DI MARCHI RD, PARK GD, PRAMMING S, KOIVISTO VA (1999). Insulin analogues and their potential in the management of diabetes mellitus. Diabetologia 42: 1151-1167.

BOONSTRA J, POST JA (2004). Molecular events associated with reactive oxygen species and cell cycle progression in mammalian cells. Gene 337: 1-13.

BRUIN JE, ERENER S, VELA J, HU X, JOHNSON JD, KURATA HT, LYNN FC, PIRET JM, ASADI A, REZANIAA, KIEFFER TJ (2014). Characterization of polyhormonal insulin-producing cells derived in vitro from human embryonic stem cells. Stem Cell Res 12: 194-208.

CERDÁ-ESTEBAN N, NAUMANN H, RUZITTU S, MAH N, PONGRAC IM, COZZITORTO C, HOMMEL A, ANDRADE-NAVARRO MA, BONIFACIO E, SPAGNOLI FM (2017). Stepwise reprogramming of liver cells to a pancreas progenitor state by the transcriptional regulator Tgif2. Nat Commun 8: 14127.

CHEN Y-J, FINKBEINER SR, WEINBLATT D, EMMETT MJ, TAMEIRE F, YOUSEFI M, YANG C, MAEHR R, ZHOU Q, SHEMER R, DOR Y, LI C, SPENCE JR, STANGER BZ (2014). De Novo Formation of Insulin-Producing "Neo- $\beta$ Cell Islets" from Intestinal Crypts. Cell Rep 6: 1046-1058.

CHENG C-W, VILLANI V, BUONO R, WEI M, KUMAR S, YILMAZ OH, COHEN P, SNEDDON JB, PERIN L, LONGO VD (2017). Fasting-Mimicking Diet Promotes Ngn3-Driven $\beta$-Cell Regeneration to Reverse Diabetes. Cell 168: 775-788.e12.

CHO J-H, KIM J-W, SHIN J-A, SHIN J, YOON K-H (2011). $\beta$-cell mass in people with type 2 diabetes. J Diabetes Investig 2: 6-17.

COURTNEY M, GJERNES E, DRUELLE N, RAVAUD C, VIEIRAA, BEN-OTHMAN N, PFEIFER A, AVOLIO F, LEUCKX G, LACAS-GERVAIS S, BUREL-VANDENBOS F, AMBROSETTI D, HECKSHER-SORENSEN J, RAVASSARD P, HEIMBERG H, MANSOURI A, COLLOMBAT P (2013). The inactivation of Arx in pancreatic $\alpha$-cells triggers their neogenesis and conversion into functional $\beta$-like cells. PLOS Genet 9: e1003934.

D'AMOUR KA, BANG AG, ELIAZER S, KELLY OG, AGULNICK AD, SMART NG, MOORMAN MA, KROON E, CARPENTER MK, BAETGE EE (2006). Production of pancreatic hormone-expressing endocrine cells from human embryonic stem cells. Nat Biotechnol 24: 1392-1401.

DAHAN T, ZIV O, HORWITZ E, ZEMMOUR H, LAVI J, SWISA A, LEIBOWITZ G, ASHCROFT FM, IN'T VELD P, GLASER B, DOR Y (2017). Pancreatic $\beta$-Cells Express the Fetal Islet Hormone Gastrin in Rodent and Human Diabetes. Diabetes 66: $426-436$.
DALLE S, BURCELIN R, GOURDY P (2013). Specific actions of GLP-1 receptor agonists and DPP4 inhibitors for the treatment of pancreatic $\beta$-cell impairments in type 2 diabetes. Cell Signal 25: 570-579.

DAVIS RL, WEINTRAUB H, LASSAR AB (1987). Expression of a single transfected cDNA converts fibroblasts to myoblasts. Cell 51: 987-1000.

DELASPRE F, BEER RL, ROVIRA M, HUANG W, WANG G, GEE S, VITERY M del C, WHEELAN SJ, PARSONS MJ (2015). Centroacinar Cells Are Progenitors That Contribute to Endocrine Pancreas Regeneration. Diabetes 64: 3499-3509.

DIRICE E, WALPITA D, VETERE A, MEIER BC, KAHRAMAN S, HU J, DANČíK V, BURNS SM, GILBERT TJ, OLSON DE, A. P, CLEMONS,, ROHIT N. KULKARNI1 and BKW (2016). Inhibition of DYRK1A stimulates human beta-cell proliferation. Diabetes 2215: 1-53.

DONATHMY, HALBAN PA(2004). Decreased beta-cell mass in diabetes: significance, mechanisms and therapeutic implications. Diabetologia 47: 581-589.

DORY, BROWN J, MARTINEZOI, MELTOND a (2004). Adult pancreatic beta-cells are formed by self-duplication rather than stem-cell differentiation. Nature 429: 41-46.

DORRELL C, SCHUG J, CANADAY PS, RUSS HA, TARLOW BD, GROMPE MT, HORTON T, HEBROK M, STREETER PR, KAESTNER KH, GROMPE M (2016). Human islets contain four distinct subtypes of $\beta$ cells. Nat Commun 7: 11756.

DUAN FF, LIU JH, MARCH JC (2015). Engineered commensal bacteria reprogram intestinal cells into glucose-responsive insulin-secreting cells for the treatment of diabetes. Diabetes 64: 1794-1803.

FERBER S, HALKIN A, COHEN H, BER I, EINAV Y, GOLDBERG I, BARSHACK I, SEIJFFERS R, KOPOLOVIC J, KAISER N, KARASIK A (2000). Pancreatic and duodenal homeobox gene 1 induces expression of insulin genes in liver and ameliorates streptozotocin-induced hyperglycemia. Nat Med 6: 568-572.

FU W, FARACHE J, CLARDY SM, HATTORI K, MANDER P, LEE K, RIOJA I, WEISSLEDER R, PRINJHA RK, BENOIST C, MATHIS D (2014). Epigenetic modulation of type-1 diabetes via a dual effect on pancreatic macrophages and $\beta$ cells. Elife 3: e04631. doi: 10.7554/eLife.04631

GHAYE AP, BERGEMANN D, TARIFEÑO-SALDIVIA E, FLASSE LC, VON BERG V, PEERS B, VOZML, MANFROIDI (2015). Progenitor potential of nkx6.1-expressing cells throughout zebrafish life and during beta cell regeneration. BMC Biol 13: 70 .

GOMEZ DL, O'DRISCOLL M, SHEETS TP, HRUBAN RH, OBERHOLZER J, MCGARRIGLE JJ, SHAMBLOTT MJ (2015). Neurogenin 3 Expressing Cells in the Human Exocrine Pancreas Have the Capacity for Endocrine Cell Fate. PLoS One 10: e0133862.

GREGG BE, MOORE PC, DEMOZAY D, HALL BA, LI M, HUSAIN A, WRIGHT AJ, ATKINSON MA, RHODES CJ (2012). Formation of a human $\beta$-cell population within pancreatic islets is set early in life. J Clin Endocrinol Metab 97: 3197-3206.

GUO S, DAI C, GUO M, TAYLOR B, HARMON JS, SANDER M, ROBERTSON RP, POWERS AC, STEIN R (2013). Inactivation of specific $\beta$ cell transcription factors in type 2 diabetes. J Clin Invest 123: 3305-3316.

GUPTA D, KONO T, EVANS-MOLINA C (2010). The role of peroxisome proliferatoractivated receptor $\gamma$ in pancreatic $\beta$ cell function and survival: therapeutic implications for the treatment of type 2 diabetes mellitus. Diabetes, Obes Metab 12: 1036-1047.

HAM D-S, SHIN J, KIM J-W, PARK H-S, CHO J-H, YOON K-H (2013). Generation of Functional Insulin-Producing Cells from Neonatal Porcine Liver-Derived Cells by PDX1/NP16, BETA2/NeuroD and MafA Ed. K Maedler. PLoS One 8: e79076.

HEALTH QUALITY ONTARIO (2015). Pancreas Islet Transplantation for Patients With Type 1 Diabetes Mellitus: A Clinical Evidence Review. Ont Health Technol Assess Ser 15: 1-84.

HILL JH, FRANZOSA EA, HUTTENHOWER C, GUILLEMIN K (2016). A conserved bacterial protein induces pancreatic beta cell expansion during zebrafish development. Elife 5. pii: e20145. doi: 10.7554/eLife.20145.

JACOVETTI C, MATKOVICH SJ, RODRIGUEZ-TREJO A, GUAY C, REGAZZI R (2015). Postnatal $\beta$-cell maturation is associated with islet-specific microRNA changes induced by nutrient shifts at weaning. Nat Commun 6: 8084 .

JOHANSSON KA, DURSUN U, JORDAN N, GU G, BEERMANN F, GRADWOHL G, GRAPIN-BOTTONA (2007). Temporal control of neurogenin3 activity in pancreas progenitors reveals competence windows for the generation of different endocrine cell types. Dev Cell 12: 457-465.

JOHNSTON NR, MITCHELL RK, HAYTHORNE E, PESSOA MP, SEMPLICI F, FERRER J, PIEMONTI L, MARCHETTI P, BUGLIANI M, BOSCO D, BERISHVILI E, DUNCANSON P, WATKINSON M, BROICHHAGEN J, TRAUNER D, RUTTER GA, HODSON DJ (2016). Beta Cell Hubs Dictate Pancreatic Islet Responses to 
Glucose. Cell Metab 24: 389-401.

KAHN SE (2003). The relative contributions of insulin resistance and beta-cell dysfunction to the pathophysiology of Type 2 diabetes. Diabetologia 46: 3-19.

KARSLIOGLU E, KLEINBERGER JW, SALIM FG, COX AE, TAKANE KK, SCOTT DK, STEWART AF (2011). cMyc is a principal upstream driver of beta-cell proliferation in rat insulinoma cell lines and is an effective mediator of human beta-cell replication. Mol Endocrinol 25: 1760-1772.

KIM H, TOYOFUKU Y, LYNN FC, CHAK E, UCHIDA T, MIZUKAMI H, FUJITANI Y, KAWAMORI R, MIYATSUKA T, KOSAKA Y, YANG K, HONIG G, VAN DER HART M, KISHIMOTO N, WANG J, YAGIHASHI S, TECOTT LH, WATADA H, GERMAN MS (2010). Serotonin regulates pancreatic beta cell mass during pregnancy. Nat Med 16: 804-808.

KLÖPPEL G, LÖHR M, HABICH K, OBERHOLZER M, HEITZPU (1985). Islet pathology and the pathogenesis of type 1 and type 2 diabetes mellitus revisited. Surv Synth Pathol Res 4: 110-125.

KOBAYASHI M, KIKUCHI O, SASAKI T, KIM H-J, YOKOTA-HASHIMOTO H, LEE Y-S, AMANO K, KITAZUMI T, SUSANTI VY, KITAMURA YI, KITAMURA T (2012). FoxO1 as a double-edged sword in the pancreas: analysis of pancreas- and $\beta$-cellspecific FoxO1 knockout mice. Am J Physiol Endocrinol Metab 302: E603-E613.

KROONE, MARTINSONLA, KADOYAK, BANGAG, KELLYOG, ELIAZERS, YOUNG H, RICHARDSON M, SMART NG, CUNNINGHAM J, AGULNICK AD, D'AMOUR KA, CARPENTER MK, BAETGE EE (2008). Pancreatic endoderm derived from human embryonic stem cells generates glucose-responsive insulin-secreting cells in vivo. Nat Biotechnol 26: 443-452.

KULKARNI RN, MIZRACHI E-B, OCANA AG, STEWART AF (2012). Human $\beta$-cell proliferation and intracellular signaling: driving in the dark without a road map. Diabetes 61: 2205-2213.

LEE J, SUGIYAMA T, LIU Y, WANG J, GU X, LEI J, MARKMANN JF, MIYAZAKI S, MIYAZAKI J, SZOT GL, BOTTINO R, KIM SK (2013). Expansion and conversion of human pancreatic ductal cells into insulin-secreting endocrine cells. Elife 2 .

LEWISEC, BLAABJERG L, STØRLING J, RONNSG, MASCAGNIP, DINARELLOCA, MANDRUP-POULSEN T (2011). The oral histone deacetylase inhibitor ITF2357 reduces cytokines and protects islet $\beta$ cells in vivo and in vitro. MolMed 17:369-77.

LI W, CAVELTI-WEDER C, ZHANG Y, ZHANG Y, CLEMENT K, DONOVAN S, GONZALEZ G, ZHU J, STEMANN M, XU K, HASHIMOTO T, YAMADA T, NAKANISHI M, ZHANG Y, ZENG S, GIFFORD D, MEISSNER A, WEIR G, ZHOU Q (2014). Long-term persistence and development of induced pancreatic beta cells generated by lineage conversion of acinar cells. Nat Biotechnol 32: 1223-30.

LU J, LIU K, SCHULZ N, KARAMPELIAS C, CHARBORD J, HILDING A, RAUTIO L, BERTOLINO P, ÖSTENSON C, BRISMAR K, ANDERSSON O (2016). IGFBP1 increases $\beta$-cell regeneration by promoting $\alpha$ - to $\beta$-cell transdifferentiation. EMBO J 35: 2026-2044.

MATSUDA H, MULLAPUDI ST, ZHANG Y, HESSELSON D, STAINIER DYR (2017). Thyroid Hormone Coordinates Pancreatic Islet Maturation During the Zebrafish Larval to Juvenile Transition to Maintain Glucose Homeostasis. Diabetes: db161476.

MATVEYENKO A V, BUTLER PC (2008). Relationship between beta-cell mass and diabetes onset. Diabetes Obes Metab 10 Suppl 4: 23-31.

MEIERJJ, BUTLERAE, SAISHOY, MONCHAMPT, GALASSOR, BHUSHANA, RIZZA RA, BUTLER PC (2008). Beta-cell replication is the primary mechanism subserving the postnatal expansion of beta-cell mass in humans. Diabetes 57: 1584-94.

VAN DER MEULEN T, MAWLA AM, DIGRUCCIO MR, ADAMS MW, NIES V, DÓLLEMAN S, LIU S, ACKERMANN AM, CÁCERES E, HUNTER AE, KAESTNER KH, DONALDSON CJ, HUISING MO (2017). Virgin Beta Cells Persist throughout Life at a Neogenic Niche within Pancreatic Islets. Cell Metab 25: 911-926.e6.

MIYATSUKA T, KANETO H, KAJIMOTO Y, HIROTA S, ARAKAWA Y, FUJITANI Y, UMAYAHARAY, WATADAH, YAMASAKI Y, MAGNUSON MA, MIYAZAKI J, HORI $M(2003)$. Ectopically expressed PDX-1 in liver initiates endocrine and exocrine pancreas differentiation but causes dysmorphogenesis. Biochem Biophys Res Commun 310: 1017-1025.

MUSSMANN R, GEESE M, HARDER F, KEGEL S, ANDAG U, LOMOW A, BURK U, ONICHTCHOUK D, DOHRMANN C, AUSTEN M (2007). Inhibition of GSK3 Promotes Replication and Survival of Pancreatic Beta Cells. J Biol Chem 282: 12030-12037.

MUSSO G, GAMBINO R, CASSADER M (2011). Interactions between gut microbiota and host metabolism predisposing to obesity and diabetes. Annu Rev Med 62: $361-380$.
NINOV N, HESSELSON D, GUT P, ZHOU A, FIDELIN K, STAINIER DYR (2013), Metabolic regulation of cellular plasticity in the pancreas. Curr Biol23: 1242-1250.

NIR T, MELTON DA, DOR Y (2007). Recovery from diabetes in mice by beta cell regeneration. J Clin Invest 117: 2553-2561.

OGURTSOVAK, DAROCHAFERNANDES JD, HUANG Y, LINNENKAMPU, GUARIGUATAL, CHO NH, CAVAN D, SHAW JE, MAKAROFF LE (2017). IDF Diabetes Atlas: Global estimates for the prevalence of diabetes for 2015 and 2040. Diabetes Res Clin Pract 128: 40-50.

EL OUAAMARI A, DIRICE E, GEDEON N, HU J, ZHOU J-Y, SHIRAKAWA J, HOU L, GOODMAN J, KARAMPELIAS C, QIANG G, et al., (2016). SerpinB1 Promotes Pancreatic $\beta$ Cell Proliferation. Cell Metab 23: 194-205.

PAGLIUCA FW, MELTON DA (2013). How to make a functional $\beta$-cell. Development 140: 2472-2483.

PAGLIUCA FW, MILLMAN JR, GÜRTLER M, SEGEL M, VAN DERVORT A, RYU JH, PETERSON QP, GREINER D, MELTON DA (2014). Generation of functional human pancreatic $\beta$ cells in vitro. Cell 159: 428-439.

PAN FC, WRIGHT C (2011). Pancreas organogenesis: from bud to plexus to gland. Dev Dyn 240: 530-565.

PASQUALI L, GAULTON KJ, RODRÍGUEZ-SEGUÍ SA, MULARONI L, MIGUELESCALADA I, AKERMAN I, TENA JJ, MORÁN I, GÓMEZ-MARÍN C, VAN DE BUNT M, et al., (2014). Pancreatic islet enhancer clusters enriched in type 2 diabetes risk-associated variants. Nat Genet 46: 136-143. Available at: http:// www.nature.com/doifinder/10.1038/ng.2870.

PATEL T, PATEL V, SINGH R, JAYARAMAN S (2011). Chromatin remodeling resets the immune system to protect against autoimmune diabetes in mice. Immunol Cell Biol 89: 640-649.

POITOUT V, ROBERTSON RP (2008). Glucolipotoxicity: Fuel Excess and $\beta$-Cell Dysfunction. Endocr Rev 29: 351-366.

QIN J, LI R, RAES J, ARUMUGAM M, BURGDORF KS, MANICHANH C, NIELSEN T, PONS N, LEVENEZ F, YAMADA T, et al., (2010). A human gut microbial gene catalogue established by metagenomic sequencing. Nature 464: 59-65.

QIU W-L, ZHANG Y-W, FENG Y, LI L-C, YANG L, XU C-R (2017). Deciphering Pancreatic Islet $\beta$ Cell and $\alpha$ Cell Maturation Pathways and Characteristic Features at the Single-Cell Level. Cell Metab 25: 1194-1205.e4.

QUIANZON CC, CHEIKH I (2012). History of insulin. J Community Hosp Intern Med Perspect 2: 18701

REZANIAA, BRUIN JE, ARORAP, RUBINA, BATUSHANSKYI, ASADI A, O'DWYER S, QUISKAMP N, MOJIBIAN M, ALBRECHTT, YANG YHC, JOHNSON JD, KIEFFER TJ (2014). Reversal of diabetes with insulin-producing cells derived in vitro from human pluripotent stem cells. Nat Biotechnol 32: 1121-1133.

RICORDI C, STROM TB (2004). Clinical islet transplantation: advances and immunological challenges. Nat Rev Immunol 4: 259-268.

RUSS HA, PARENT A V, RINGLER JJ, HENNINGS TG, NAIR GG, SHVEYGERT M, GUO T, PURI S, HAATAJA L, CIRULLI V, BLELLOCH R, SZOT GL, ARVAN $P$, HEBROK M (2015). Controlled induction of human pancreatic progenitors produces functional beta-like cells in vitro. EMBO J 34: 1759-1772.

SAISHO Y, BUTLER AE, MANESSO E, ELASHOFF D, RIZZA RA, BUTLER PC (2013). $\beta$-cell mass and turnover in humans: effects of obesity and aging. Diabetes Care 36: 111-117.

SCHONHOFF SE, GIEL-MOLONEYM, LEITERAB (2004). Neurogenin 3-expressing progenitor cells in the gastrointestinal tract differentiate into both endocrine and non-endocrine cell types. Dev Biol 270: 443-454.

SHAMSI F, PARLATO R, COLLOMBAT P, MANSOURI A (2014). A genetic mouse model for progressive ablation and regeneration of insulin producing beta-cells. Cell Cycle 13: 3948-3957.

SHIMODA M, KANDA Y, HAMAMOTO S, TAWARAMOTO K, HASHIRAMOTO M, MATSUKI M, KAKU K (2011). The human glucagon-like peptide-1 analogue liraglutide preserves pancreatic beta cells via regulation of cell kinetics and suppression of oxidative and endoplasmic reticulum stress in a mouse model of diabetes. Diabetologia 54: 1098-1108.

SINGH SP, JANJUHA S, HARTMANN T, KAYISOGLU Ö, KONANTZ J, BIRKE S, MURAWALAP, ALFAREA, MURATAK, EUGSTERA, TSUJIN, MORRISSEYER, BRAND M, NINOV N (2017). Different developmental histories of beta-cells generate functional and proliferative heterogeneity during islet growth. Nat Commun 8: 664 .

SOLARM, CARDALDAC, HOUBRACKEN I, MARTÍN M, MAESTRO MA, DE MEDTS 
N, XU X, GRAU V, HEIMBERG H, BOUWENS L, FERRER J (2009). Pancreatic exocrine duct cells give rise to insulin-producing beta cells during embryogenesis but not after birth. Dev Cell 17: 849-860.

SQUIFFLET J-P, GRUESSNER RWG, SUTHERLAND DER (2008). The history of pancreas transplantation: past, present and future. Acta Chir Belg 108: 367-378.

STOLOVICH-RAIN M, ENK J, VIKESA J, NIELSEN FC, SAADA A, GLASER B, DOR Y (2015). Weaning triggers a maturation step of pancreatic $\beta$ cells. Dev Cell 32: 535-545.

TAKAHASHI K, TANABE K, OHNUKI M, NARITA M, ICHISAKA T, TOMODA K, YAMANAKAS (2007). Induction of pluripotent stem cells from adult human fibroblasts by defined factors. Cell 131: 861-872.

TALCHAI C, XUAN S, KITAMURA T, DEPINHO RA, ACCILI D (2012). Generation of functional insulin-producing cells in the gut by Foxo1 ablation. Nat Genet 44: 406-412, S1.

TALCHAI C, XUAN S, LIN H V., SUSSEL L, ACCILI D (2012). Pancreatic $\beta$ Cell Dedifferentiation as a Mechanism of Diabetic $\beta$ Cell Failure. Cell 150: 1223-1234.

TAYLOR BL, LIU F-F, SANDER M (2013). Nkx6.1 is essential for maintaining the functional state of pancreatic beta cells. Cell Rep 4: 1262-1275.

THOMSON JA, ITSKOVITZ-ELDOR J, SHAPIRO SS, WAKNITZ MA, SWIERGIEL JJ, MARSHALL VS, JONES JM (1998). Embryonic stem cell lines derived from human blastocysts. Science 282: 1145-1147.

THOREL F, NÉPOTE V, AVRIL I, KOHNO K, DESGRAZ R, CHERA S, HERRERA $\mathrm{PL}$ (2010). Conversion of adult pancreatic alpha-cells to beta-cells after extreme beta-cell loss. Nature 464: 1149-1154.

TRAPNELL C, CACCHIARELLI D, GRIMSBY J, POKHAREL P, LI S, MORSE M, LENNON NJ, LIVAK KJ, MIKKELSEN TS, RINN JL (2014). The dynamics and regulators of cell fate decisions are revealed by pseudotemporal ordering of single cells. Nat Biotechnol 32: 381-386.

TSUJI N, NINOV N, DELAWARY M, OSMAN S, ROH AS, GUT P, STAINIER DYR (2014). Whole organism high content screening identifies stimulators of pancreatic beta-cell proliferation. PLoS One 9: e104112.

VALDEZIA, DIRICE E, GUPTAMK, SHIRAKAWAJ, TEOAKK, KULKARNI RN (2016). Proinflammatory Cytokines Induce Endocrine Differentiation in Pancreatic Ductal Cells via STAT3-Dependent NGN3 Activation. Cell Rep 15: 460-470.

WALPITAD, HASAKAT, SPOONAMOREJ, VETEREA, TAKANEKK, FOMINA-YADLIN D, FIASCHI-TAESCH N, SHAMJI A, CLEMONS PA, STEWART AF, SCHREIBER SL, WAGNER BK (2012). A human islet cell culture system for high-throughput screening. J Biomol Screen 17: 509-518.

WANG G, RAJPUROHIT SK, DELASPRE F, WALKER SL, WHITE DT, CEASRINE A, KURUVILLA R, LI R-J, SHIM JS, LIU JO, PARSONS MJ, MUMM JS (2015). First quantitative high-throughput screen in zebrafish identifies novel pathways for increasing pancreatic $\beta$-cell mass. Elife 4. doi: 10.7554/eLife.08261.
WANG P, ALVAREZ-PEREZJ-C, FELSENFELD DP, LIU H, SIVENDRANS, BENDER A, KUMARA, SANCHEZR, SCOTTDK, GARCIA-OCAÑAA, STEWARTAF (2015). A high-throughput chemical screen reveals that harmine-mediated inhibition of DYRK1A increases human pancreatic beta cell replication. Nat Med 21:383-388.

WANG P, FIASCHI-TAESCH NM, VASAVADA RC, SCOTT DK, GARCÍA-OCAÑAA, STEWART AF (2015). Diabetes mellitus-advances and challenges in human $\beta$-cell proliferation. Nat Rev Endocrinol 11: 201-212.

WANG Z, YORK NW, NICHOLS CG, REMEDI MS (2014). Pancreatic $\beta$ Cell Dedifferentiation in Diabetes and Redifferentiation following Insulin Therapy. Cell Metab 19: 872-882

XIEM, YEH, WANG H, CHARPIN-ELHAMRI G, LORMEAU C, SAXENAP, STELLING J, FUSSENEGGER M (2016). $\beta$-cell-mimetic designer cells provide closed-loop glycemic control. Science 354: 1296-1301.

YANG Y-P, THOREL F, BOYER DF, HERRERA PL, WRIGHT CVE (2011). Contextspecific $\alpha$ - to- $\beta$-cell reprogramming by forced Pdx 1 expression. Genes Dev 25 $1680-1685$.

YE L, ROBERTSON MA, HESSELSON D, STAINIER DYR, ANDERSON RM (2015) glucagon is essential for alpha cell transdifferentiation and beta cell neogenesis. Development 142: 1407-1417.

YOSHIHARAE, WEIZ, LIN CS, FANG S, AHMADIAN M, KIDA Y, TSENG T, DAI Y, YU RT, LIDDLE C, ATKINS AR, DOWNES M, EVANS RM (2016). ERR $\gamma$ Is Required for the Metabolic Maturation of Therapeutically Functional Glucose-Responsive $\beta$ Cells. Cell Metab 23: 622-634.

YOSHIOKA M, KAYO T, IKEDA T, KOIZUMI A (1997). A novel locus, Mody4, distal to D7Mit189 on chromosome 7 determines early-onset NIDDM in nonobese C57BL/6 (Akita) mutant mice. Diabetes 46: 887-894.

ZENG C, MULAS F, SUI Y, GUAN T, MILLER N, TAN Y, LIU F, JIN W, CARRANO AC, HUISING MO, SHIRIHAI OS, YEO GW, SANDER M (2017). Pseudotempora Ordering of Single Cells Reveals Metabolic Control of Postnatal $\beta$ Cell Proliferation. Cell Metab 25: 1160-1175.e11.

ZHANG C, MORIGUCHIT, KAJIHARAM, ESAKIR, HARADAA, SHIMOHATAH, OISH H, HAMADA M, MORITO N, HASEGAWA K, KUDO T, ENGEL JD, YAMAMOTO M, TAKAHASHI S (2005). MafA is a key regulator of glucose-stimulated insulin secretion. Mol Cell Biol 25: 4969-4976.

ZHANG Y, FAVA GE, WANG H, MAUVAIS-JARVIS F, FONSECA VA, WU H (2016). PAX4 Gene Transfer Induces $\alpha$-to- $\beta$ Cell Phenotypic Conversion and Confers Therapeutic Benefits for Diabetes Treatment. Mol Ther 24: 251-260.

ZHOU Q, BROWN J, KANAREK A, RAJAGOPAL J, MELTON DA (2008). In vivo reprogramming of adult pancreatic exocrine cells to beta-cells. Nature 455:627-632.

ZHU S, RUSS HA, WANG X, ZHANG M, MA T, XU T, TANG S, HEBROK M, DING $S$ (2016). Human pancreatic beta-like cells converted from fibroblasts. Nat Commun 7: 10080 . 


\section{Further Related Reading, published previously in the Int. J. Dev. Biol.}

Induction of differentiation of undifferentiated cells into pancreatic beta cells in vertebrates

Masaki Hosoya, Yuya Kunisada, Akira Kurisaki and Makoto Asashima

Int. J. Dev. Biol. (2012) 56: 313-323

https://doi.org/10.1387/ijdb.123522mh

Characterization of mouse embryonic stem cell differentiation into the pancreatic lineage in vitro by transcriptional profiling, quantitative RT-PCR and immunocytochemistry

Alexandra Rolletschek, Insa S. Schroeder, Herbert Schulz, Oliver Hummel, Norbert Huebner and Anna M. Wobus

Int. J. Dev. Biol. (2010) 54: 41-54

https://doi.org/10.1387/ijdb.082694ar

Mouse ES cells over-expressing the transcription factor NeuroD1 show increased differentiation towards endocrine lineages and insulin-expressing cells

Mélanie Marchand, Insa S. Schroeder, Suzy Markossian, Anouchka Skoudy, Didier Nègre, François-Loïc Cosset, Paco Real, Christian Kaiser, Anna M. Wobus and Pierre Savatier

Int. J. Dev. Biol. (2009) 53: 569-578

https://doi.org/10.1387/ijdb.092856mm

\section{Genes controlling pancreas ontogeny}

Claire Bonal and Pedro L. Herrera

Int. J. Dev. Biol. (2008) 52: 823-835

https://doi.org/10.1387/ijdb.072444cb

\section{C/EBPalpha and C/EBPbeta are markers of early liver development}

Adam Westmacott, Zoë D. Burke, Guillermo Oliver, Jonathan M.W. Slack and David Tosh

Int. J. Dev. Biol. (2006) 50: 653-657

https://doi.org/10.1387/ijdb.062146aw

Interplay between FGF10 and Notch signalling is required for the self-renewal of pancreatic progenitors

Francisco Miralles, Luciane Lamotte, Dominique Couton and Rajiv L. Joshi

Int. J. Dev. Biol. (2006) 50: 17-26

https://doi.org/10.1387/ijdb.052080fm

Expression of regulatory genes for pancreas development during murine embryonic stem cell differentiation

Josué K. Mfopou, Erik Willems, Luc Leyns and Luc Bouwens

Int. J. Dev. Biol. (2005) 49: 915-922

http://www.intjdevbiol.com/web/paper/052004jm

5 yr ISI Impact Factor $(2016)=2.421$
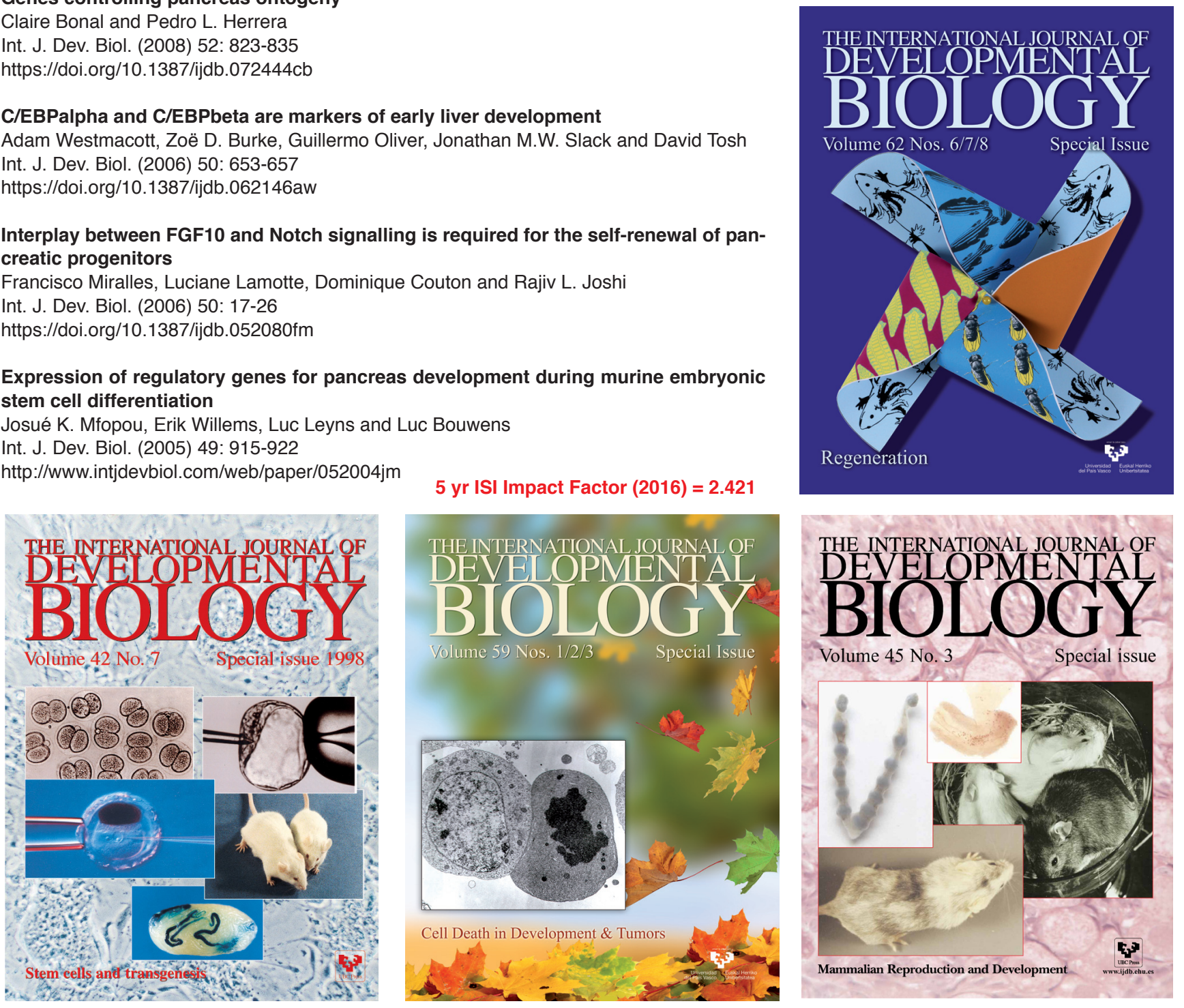